\title{
Predictive Value of Micronucleus Count in Cervical Intraepithelial Neoplasia and Carcinoma
}

\author{
Mikronükleus Sayımının Servikal İntraepitelyal Neoplazi \\ ve Karsinomda Prediktif Değeri
}

\author{
Marie Moses AMBROISE, Kanchana BALASUNDARAM, Manjiri PHANSALKAR \\ Department of Pathology, Pondicherry Institute of Medical Sciences (PIMS), PUDUCHERRY, INDIA
}

The article was presented in part at 39th Annual KCIAPM State Conference, on 08.09.2012, Bangalore, India.

\begin{abstract}
Objective: A micronucleus is a small additional nucleus formed due to chromosomal loss or fragmentation. The aim of this study was to assess the utility of micronucleus count as a screening tool in cervical cancer.
\end{abstract}

Material and Method: A total of 132 cases consisting of 42 pre-neoplastic and neoplastic cases and 90 non-neoplastic cases were studied. Only routine Papanicolaou-stained cervical smears were used. In each smear, the number of micronucleated cells and binucleated cells were counted under oil immersion and expressed as a count per 1,000 cells. The micronucleated and binucleated cell counts in pre-neoplastic, neoplastic and non-neoplastic categories were compared for statistical significance. The counts were also correlated with age, duration of marital life, number of pregnancies and abortions

Results: The micronucleus count and the binucleated cell count were significantly higher in the high -grade squamous intraepithelial lesion (HSIL) and invasive carcinoma categories compared to low -grade squamous intraepithelial lesion (LSIL) and non-neoplastic cases. Receiver operating characteristic (ROC) curve analysis revealed that micronucleus count and binucleated cell count possess a high degree of sensitivity and specificity for identifying HSIL and invasive carcinoma.

Conclusion: Our results reveal that micronucleus evaluation in routine Pap smears is a very useful biomarker in cervical cancer screening. The binucleated cell count increases the predictive value of this simple test.

Key Words: Micronucleus tests, Uterine cervical neoplasms, Cervical intraepithelial neoplasia, Vaginal smear

\section{ÖZ}

Amaç: Bir mikronükleus, kromozom kaybı veya fragmentasyonu nedeniyle oluşan küçük bir ek nükleustur. Bu çalışmanın amacı servikal kanserde bir tarama aracı olarak mikronükleus sayımının değerini değerlendirmekti.

Gereç ve Yöntem: 42 preneoplastik ve neoplastik, 90 nonneoplastik olmak üzere toplam 132 olgu çalışıldı. Sadece rutin Papanicolaou ile boyanmış servikal yaymalar kullanıldı. Her yaymada mikronükleuslu hücre ve binükleuslu hücre sayısı yağ imersiyonu altında sayılıp 1000 hücre başına bir sayım olarak ifade edildi. Mikronükleuslu ve binükleuslu hücre sayımları preneoplastik, neoplastik ve nonneoplastik kategorilerde istatistiksel önem açısından karşılaştırıldı. Sayımların ayrıca yaş, evlilik süresi, hamilelik ve kürtaj sayısıyla korelasyonu araștırıldı.

Bulgular: Mikronükleus sayımı ve binükleuslu hücre sayımı yüksek dereceli skuamöz intraepitelyal lezyon (HSIL) ve invaziv karsinoma kategorilerinde düşük dereceli skuamöz intraepitelyal lezyon (LSIL) ve nonneoplastik olgularına göre önemli ölçüde daha yüksekti. ROC eğrisi analizi, mikronükleus sayımı ve binükleuslu hücre sayımının yüksek dereceli intraepitelyal lezyon ve invaziv karsinom için yüksek ölçüde duyarlı ve özgül olduğunu ortaya çıardı.

Sonuç: Elde ettiğimiz sonuçlar rutin Pap yaymalarında mikronükleus değerlendirmesinin servikal kanser taramasında çok faydalı bir biyobelirteç olduğunu göstermektedir. Binükleuslu hücre sayımı bu basit testin prediktif değerini arttırmaktadır.

Anahtar Sözcükler: Mikronükleus testleri, Uterin servikal neoplazmlar, Servikal intraepitelyal neoplazi, Vajinal yayma
(Turk Patoloji Derg 2013, 29:171-178)

Received : 24.11.2012 Accepted : 21.05.2013
Correspondence: Marie Moses AMBROISE

Plot no. 92, Veeramamunivar Street, Radhakrishna Nagar,

Thattanchavady Post, PUDUCHERRY, 605009, INDIA

E-mail:drmosesa@yahoo.com Phone: +919486852651 


\section{INTRODUCTION}

Cervical cancer is one of the most common cancers among women worldwide and the leading cause of cancer mortality in Indian women. The incidence of cervical cancer varies widely and $86 \%$ of all cases and about $88 \%$ of deaths due to cervical cancer occur in developing nations. India has the highest disease frequency with 134000 cases and 73000 deaths in 2008 (1). The conventional Pap smear is the cheapest and most commonly used investigation in screening cervical cancer. A recent study revealed a significantly lower sensitivity for cytology in detecting CIN3 or worse compared to HPV testing (53.3\% versus 92.0\%) (2). Ancillary investigations like HPV testing and p16 immunostaining can improve the sensitivity, but they are seldom used in developing nations for screening. Hence a simple procedure which can be used in conjunction with the routine cytological analysis of conventional Pap smears would be of much use in better detection of cervical intraepithelial neoplasia.

The micronucleus test is a well established and widely used technique to evaluate genetic damage resulting from exposure to carcinogenic or mutagenic agents (3-6). The genotoxic effects of chemicals are associated with several health hazards like infertility, abortions, birth defects, neurodegenerative disorders and most importantly increased incidence of cancer. A micronucleus $(\mathrm{MN})$ is an additional small nucleus in the cytoplasm, formed when chromosomes or chromosomal fragments fail to be incorporated into the nucleus during cell division. Micronucleus can detect chromosomal breakage as well as chromosomal loss and thus serves as a potential biomarker of genotoxicity $(6,7)$. Micronucleus test is helpful in biomonitoring damage resulting from chemotherapeutic drugs, radiation, poisonous chemicals and pollutants (6). The international human micronucleus (HUMN) project (www.humn.org), established in 1997 is an international collaborative program aimed to standardize micronucleus assays to study DNA damage. The MN assay in exfoliated cells is a minimally invasive method for monitoring genetic damage in humans. Micronucleus quantification in exfoliated oral mucosal cells is a simple technique used to detect genetic damage resulting from exposure to genotoxic agents like tobacco, alcohol, illicit drugs and others $(3,5)$.

The micronucleus test also serves as an excellent biomarker for predicting cancer risk (8). It has shown potential use as an ancillary tool for diagnosing malignancy in cytological samples (9-11). MN scoring has been used to assess the risk of malignant transformation in uterine cervix (12 -15). A recent study proved that $\mathrm{MN}$ scoring can be performed satisfactorily in routine Pap smears (16). The objective of our study was to evaluate MN count in a spectrum of non-neoplastic, pre-neoplastic lesions and invasive cancer of the cervix and study the association of MN count with important risk factors implicated in cervical carcinogenesis. Hence we counted the frequency of micronucleated and binucleated cells, a similar metanucleated anomaly in exfoliated epithelial cells in diverse abnormalities of the cervix.

\section{MATERIALS and METHODS}

In this retrospective study, we assessed micronuclei and binucleated cells in 132 cases that were diagnosed between January 2009 and December 2012. We included 13 cases with a diagnosis of low- grade squamous intraepithelial lesion (LSIL), 10 high- grade squamous intraepithelial lesion (HSIL) cases, 19 invasive squamous cell carcinoma (IC) cases and 90 non-neoplastic cases comprising of 20 normal, 20 inflammatory, 20 atrophic smears, and 30 cases with benign cellular changes associated with infections (10 cases of Trichomonas vaginalis, fungal organism consistent with Candida spp and bacterial vaginosis each). The diagnosis of bacterial vaginosis was considered based on the presence of clue cells.

All the cases included in the pre-malignant and malignant categories had a histopathological outcome of either cervical intraepithelial lesion (CIN) or invasive squamous cell carcinoma. The cytology slides were reallocated according to the biopsy diagnosis. Cases with scanty cellularity and dense inflammation obscuring smear details were excluded. Only conventional pap smears were used in this study. The smears in the benign category were reviewed by all the three authors independently. Clinical details like age, duration of marital life, number of pregnancies and abortions were recorded from the case files. Duration of marital life was not available for seven cases in the preneoplastic and neoplastic categories. To analyze the utility of the counts in borderline cases, we also assessed $\mathrm{MN}$ and BNC counts in 27 ASCUS cases with follow-up histology.

MN scoring: The smears were analyzed by light microscopy under oil immersion (x 1000) separately and independently by two scorers (MA and BK). A third observer (MP) also reviewed the slides after observation by the two initial scorers. Final scores were given only after overall consensus. For each case 1000 epithelial cells with well-defined nuclei and cell borders were counted. Cells showing features of degeneration and apoptotic changes were not included. Counting was avoided in cell clusters and clumped groups. Micronuclei were determined according to the following 
criteria: size less than one-third of the main nucleus, clearly included in the cytoplasm on the same optical plane as the nucleus and distinctly separate from the main nucleus with a similar staining intensity (Figures 1,2). Cells with single or double micronuclei were given a score of 1 . An overall $\mathrm{MN}$ count was expressed as the number of micronucleated cells per 1000 epithelial cells. Number of binucleated cells (BNC) were also counted. Binucleated cells have two nuclei close to each other (Figure 3). A BNC count was expressed as the number of binucleated cells per 1000 cells similar to MN count.

Statistical analysis: $\mathrm{MN}$ and $\mathrm{BNC}$ counts were expressed as mean $\pm \mathrm{SD}$ and median (min-max) where appropriate. Comparisons between two groups were performed by the nonparametric Mann-Whitney -U-test, whereas comparisons between more than two groups were performed by the Kruskal-Wallis test. Conover-Inman post-hoc test for multiple pairwise comparisons between groups was done

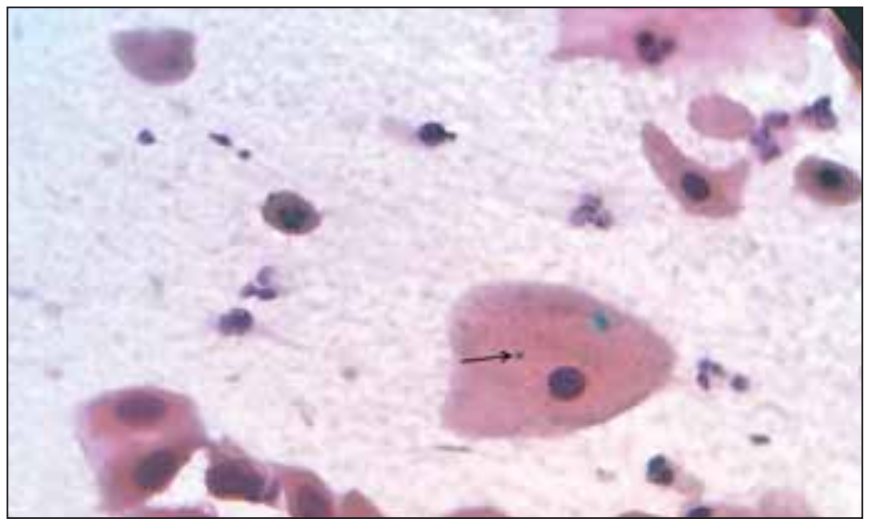

Figure 1: Micronucleus (indicated with an arrow) in a normal cell (Pap stain x1000).

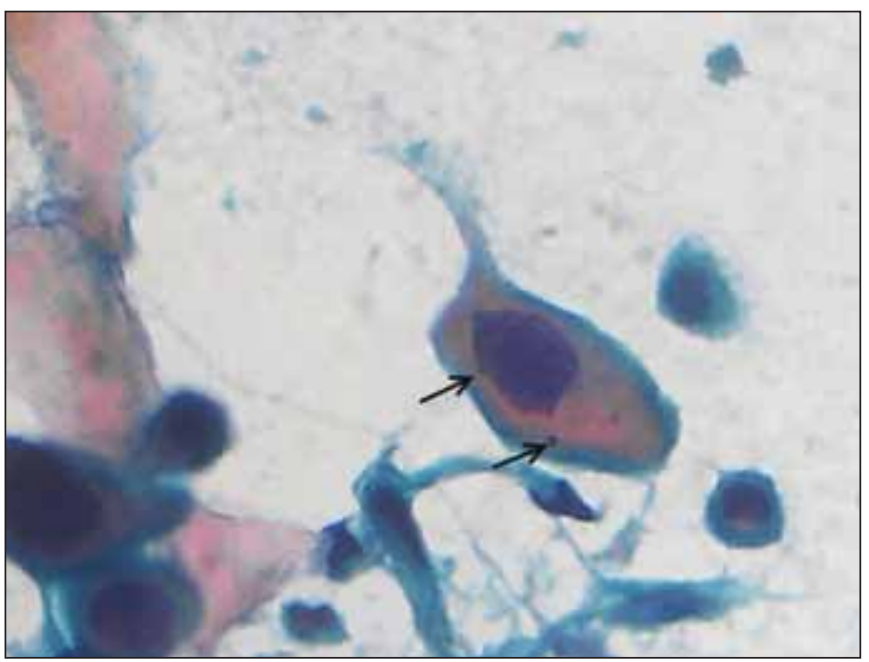

Figure 2: Micronuclei(indicated with arrows) in an atypical cell (Pap stain x1000). following a significant Kruskal -Wallis test. The predictive efficacy of MN and BNC counts was assessed using the area under the curve (AUC) generated by a receiver operating characteristic (ROC) analysis. The ROC plots the true positive rate (sensitivity) against the false-positive rate (1-specificity). A perfectly accurate test would yield a ROC of 1.0 and a ROC of 0.5 indicates a predictive efficacy no better than chance. The effect of demographic parameters like age, duration of marital life, number of pregnancies and abortions on $\mathrm{MN}$ and $\mathrm{BNC}$ counts was analyzed using simple and multiple linear regression. All reported $p$ values are two-sided and a $\mathrm{p}$ value of less than 0.05 was considered significant for all statistical tests. Data processing and analysis were performed using SPSS for Windows (Version 20.0.0) and SYSTAT version 13.1.

This study was approved by the ethics committee of our institution.

\section{RESULTS}

Micronucleated cell count and binucleated cell count for the non-neoplastic, preneoplastic and neoplastic categories are displayed in Table I. The Kruskal -Wallis test yielded significant differences for $\mathrm{MN}$ and $\mathrm{BNC}$ counts $(\mathrm{p}<0.001$ for both $\mathrm{MN}$ and BNC counts). A post-hoc ConoverInman test was used to compare individual categories and the pairwise comparisons are shown in Table II. The MN count of LSIL is significantly lower compared to HSIL and IC and significantly higher compared to the normal, atrophic, inflammatory and infectious categories. The mean $\pm \mathrm{SD}$ [ median (min-max)] MN count in smears positive for bacterial vaginosis, Trichomonas vaginalis and Candida spp were $3.6 \pm 1.6$ [3.5 (2.0-7.0) ], $4.0 \pm 1.2$ [4.0 (2.0-6.0)]

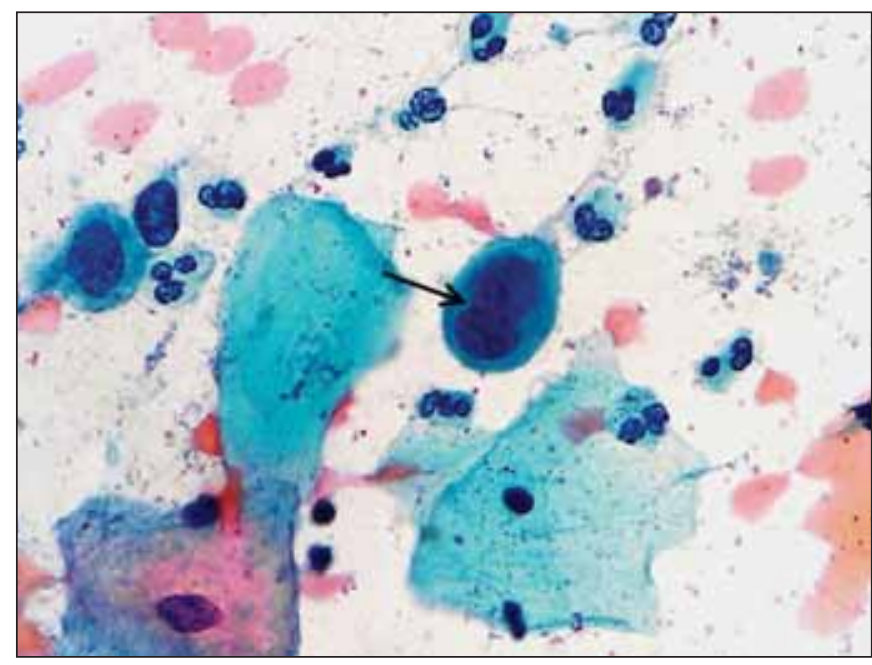

Figure 3: A binucleated cell(indicated with an arrow) (Pap stain $\mathrm{x} 1000)$. 
Table I: MN count and BNC count in each category

\begin{tabular}{|l|c|c|c|c|c|}
\hline \multirow{2}{*}{ Category } & \multirow{2}{*}{ Number of cases } & \multicolumn{2}{|c|}{ MN count } & \multicolumn{2}{c|}{ BNC count } \\
\cline { 3 - 6 } & & Mean \pm SD & Median (Min-max) & Mean \pm SD & Median (Min-max) \\
\hline Normal & 20 & $1.2 \pm 1.1$ & $1.0(0.0-4.0)$ & $0.7 \pm 0.7$ & $1.0(0.0-2.0)$ \\
\hline Atrophic & 20 & $1.3 \pm 1.1$ & $1.0(0.0-4.0)$ & $1.1 \pm 1.2$ & $1.0(0.0-4.0)$ \\
\hline Infections & 30 & $3.4 \pm 1.4$ & $3.0(1.0-7.0)$ & $1.0 \pm 1.3$ & $0.0(0.0-4.0)$ \\
\hline Inflammatory & 20 & $2.5 \pm 1.4$ & $3.0(0.0-5.0)$ & $1.0 \pm 1.1$ & $0.5(0.0-3.0)$ \\
\hline LSIL & 13 & $4.4 \pm 1.6$ & $4.0(3.0-8.0)$ & $6.7 \pm 2.7$ & $6.0(2.0-12.0)$ \\
\hline HSIL & 10 & $11.9 \pm 4.2$ & $11.5(5.0-20.0)$ & $19.0 \pm 11.6$ & $15.5(4.0-42.0)$ \\
\hline IC & 19 & $16.4 \pm 6.9$ & $15.0(9.0-39.0)$ & $16.5 \pm 6.9$ & $15.0(10.0-42.0)$ \\
\hline
\end{tabular}

MN: Micronucleus, BNC: Binucleated cells, IC: Invasive squamous cell carcinoma.

Table II: Conover-Inman test for pairwise comparisons

\begin{tabular}{|l|c|c|}
\hline $\begin{array}{l}\text { Pairwise comparison } \\
\text { between categories }\end{array}$ & $\begin{array}{c}\text { MN count } \\
\text { p value }\end{array}$ & $\begin{array}{c}\text { BNC count } \\
\text { p value }\end{array}$ \\
\hline Normal vs. Atrophic & 0.758 & 0.246 \\
\hline Normal vs. Inflammatory & $<0.001^{\star}$ & 0.497 \\
\hline Normal vs. Infections & $<0.001^{\star}$ & 0.619 \\
\hline Normal vs. LSIL & $<0.001^{\star}$ & $<0.001^{\star}$ \\
\hline Normal vs. HSIL & $<0.001^{\star}$ & $<0.001^{\star}$ \\
\hline Normal vs. IC & $<0.001^{\star}$ & $<0.001^{\star}$ \\
\hline Atrophic vs. Inflammatory & $<0.001^{\star}$ & 0.629 \\
\hline Atrophic vs. Infections & $<0.001^{\star}$ & 0.438 \\
\hline Atrophic vs. LSIL & $<0.001^{\star}$ & $<0.001^{\star}$ \\
\hline Atrophic vs. HSIL & $<0.001^{\star}$ & $<0.001^{\star}$ \\
\hline Atrophic vs. IC & $<0.001^{\star}$ & $<0.001^{\star}$ \\
\hline Inflammatory vs. Infections & $0.009^{\star}$ & 0.805 \\
\hline Inflammatory vs. LSIL & $<0.001^{\star}$ & $<0.001^{\star}$ \\
\hline Inflammatory vs. HSIL & $<0.001^{\star}$ & $<0.001^{\star}$ \\
\hline Inflammatory vs. IC & $<0.001^{\star}$ & $<0.001^{\star}$ \\
\hline Infections vs. LSIL & $0.038^{\star}$ & $<0.001^{\star}$ \\
\hline Infections vs. HSIL & $<0.001^{\star}$ & $<0.001^{\star}$ \\
\hline Infections vs. IC & $<0.001^{\star}$ & $<0.001^{\star}$ \\
\hline LSIL vs. HSIL & $<0.001^{\star}$ & $0.028^{\star}$ \\
\hline LSIL vs. IC & $<0.001^{\star}$ & $0.010^{\star}$ \\
\hline HSIL vs. IC & 0.359 & 0.970 \\
\hline
\end{tabular}

* Denotes significant $\mathrm{p}$ values.

MN: Micronucleus, BNC: Binucleated cells, IC: Invasive squamous cell carcinoma.

and $2.5 \pm 1.0$ [2.0 (1.0-4.0)] respectively. The BNC count of LSIL is significantly higher compared to the four nonneoplastic categories. The BNC count of LSIL category also differs significantly compared with HSIL and IC.
The mean \pm SD [median (min-max)] age for the seven categories are as follows: Normal-30.3 \pm 10.7 [26.0 (18.055.0)], Inflammatory-31.7 \pm 9.8 [31.0 (20.0-58.0)], Atrophy - $59.4 \pm 10.5$ [60.0 (44.0-76.0)], Infections-34.6 \pm 9.9 [34.0 (18.0-60.0)], LSIL- $41.6 \pm 6.3$ [40.0 (32.0-54.0)], HSIL$45.1 \pm 9.7[46.0(31.0-58.0)]$ and IC- $57.8 \pm 8.6[60.0$ (40.0-70.0)]. The Kruskal -Wallis test showed a significant difference for the age of the seven categories $(\mathrm{p}<0.001)$. A post-hoc Conover's test (all $\mathrm{p}$ values not shown) revealed that the age of normal, inflammatory and infectious categories was significantly lower compared to LSIL, HSIL and IC categories. The age of IC patients was significantly higher compared to LSIL ( $\mathrm{p}<0.001)$ and HSIL ( $\mathrm{p}=0.002)$. The difference noted between the age of LSIL and HSIL categories was not significant statistically $(\mathrm{p}=0.458)$.

The ability of MN and BNC counts to distinguish HSIL + lesions (HSIL or invasive squamous cell carcinoma) was analyzed using receiver operating characteristic (ROC) curve analysis. Using the ROC curve method, we found a cut-off of 8 for MN count giving a sensitivity of $96.6 \%$ and a specificity of $99.0 \%(\mathrm{p}<0.001$ and $\mathrm{AUC}=0.997)$ for detecting HSIL + lesions. Similarly a cut-off of 8 for BNC count yielded a sensitivity of $96.5 \%$ and a specificity of $96.1 \%(\mathrm{p}<0.001$ and AUC $=0.993)$ (Figure 4). The majority of the HSIL + cases (97\%) had both MN and BNC counts $\geq 8$. Only $8 \%$ of the smears in the LSIL category had both counts $\geq 8$.

We also wanted to analyze the effect of demographic parameters on $\mathrm{MN}$ and BNC counts. Figures 5-8 show the variation of $\mathrm{MN}$ and $\mathrm{BNC}$ counts with respect to age, duration of marital life, number of pregnancies and abortions. The proportion of cases with higher $\mathrm{MN}$ and $\mathrm{BNC}$ counts increased with age, duration of marital life and number of pregnancies. 


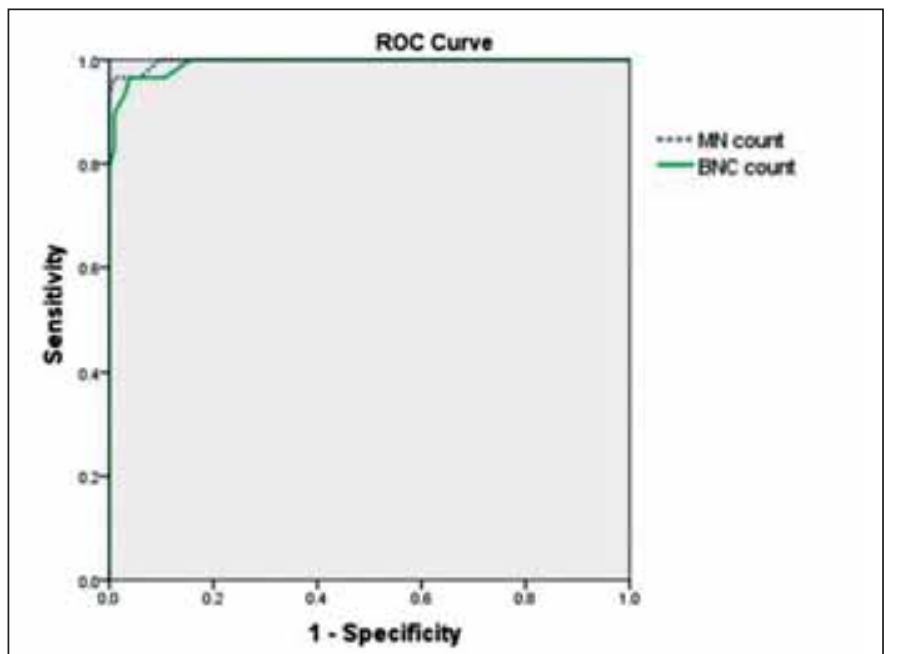

Figure 4: ROC curves for MN and BNC counts to predict HSIL+ cases.

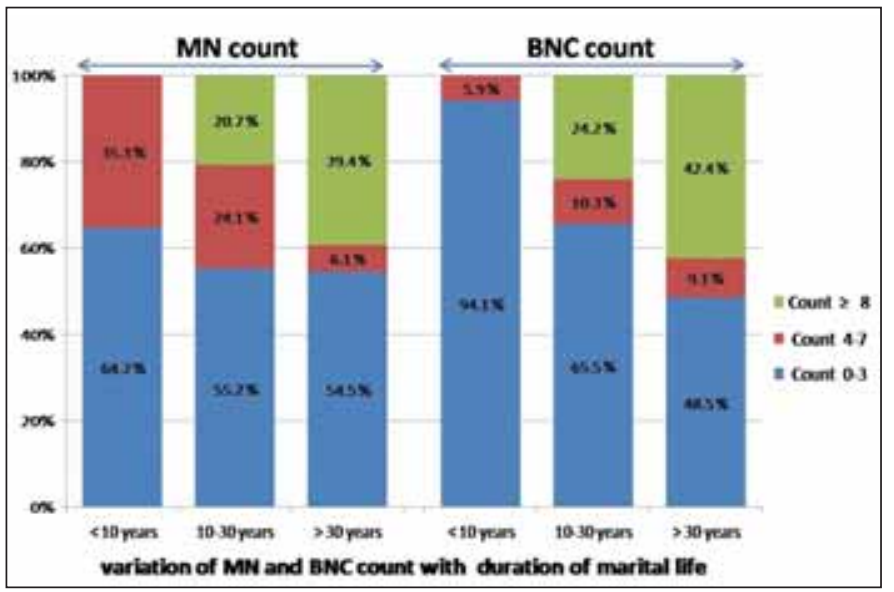

Figure 6: Variation of $\mathrm{MN}$ and $\mathrm{BNC}$ counts with duration of marital life.

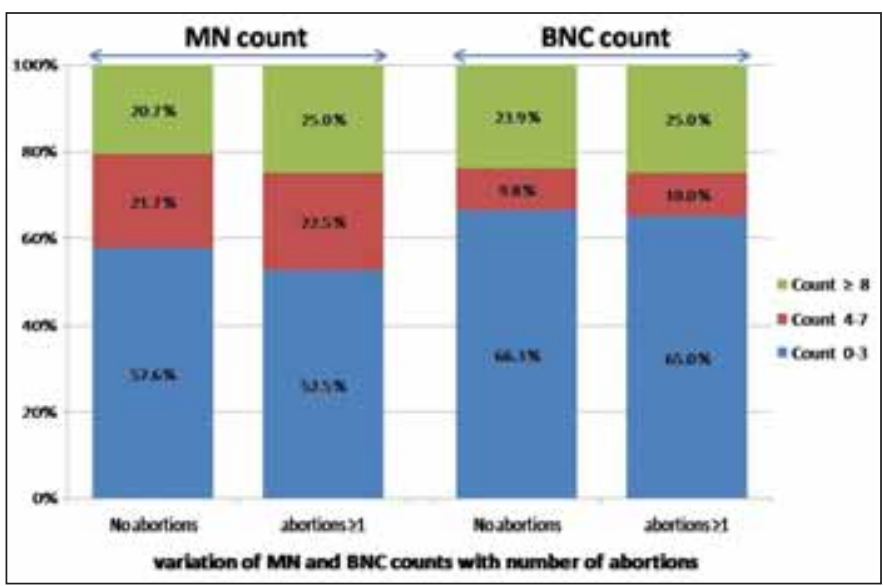

Figure 8: Variation of $\mathrm{MN}$ and $\mathrm{BNC}$ counts with number of abortions.

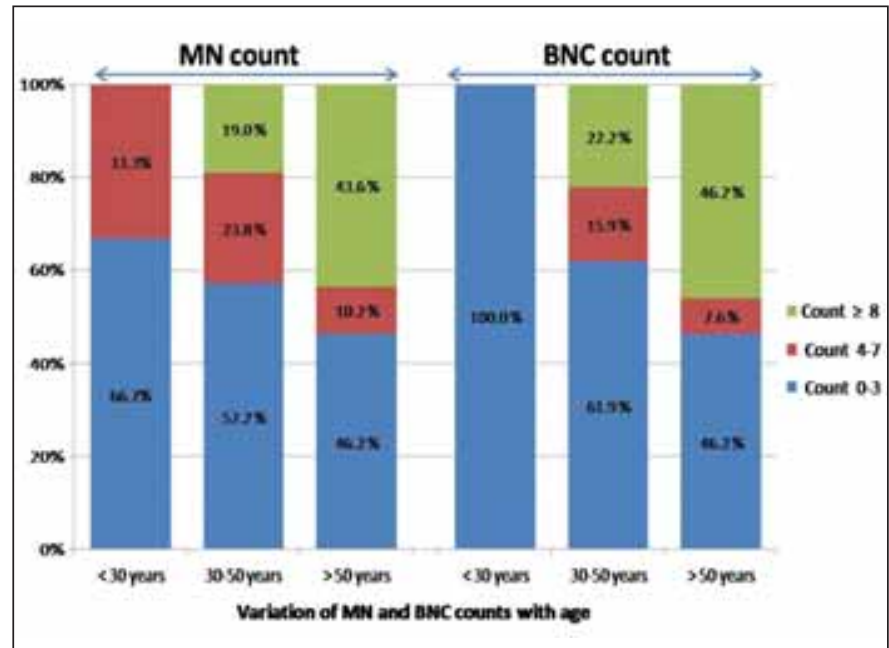

Figure 5: Variation of $\mathrm{MN}$ and $\mathrm{BNC}$ counts with age.

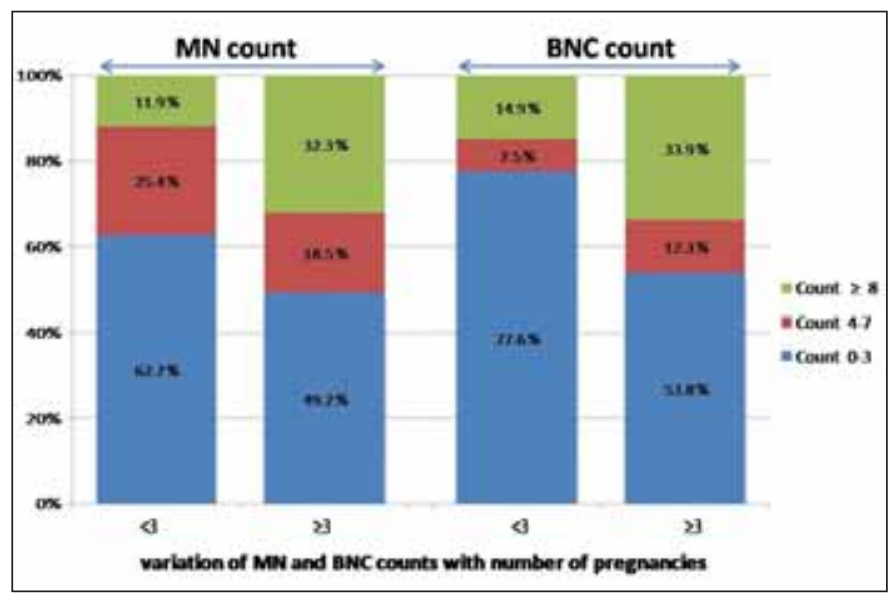

Figure 7: Variation of $\mathrm{MN}$ and $\mathrm{BNC}$ counts with number of pregnancies.

Simple linear regression analysis was performed followed by multiple linear regression to determine the relative contribution of these variables. The analysis was limited only to 125 cases since seven cases lacked complete clinical data. We assessed the predictors (age, duration of marital life, number of pregnancies and abortions and positivity for $\mathrm{CIN} / \mathrm{IC}$ ) for $\mathrm{MN}$ and $\mathrm{BNC}$ counts using simple linear regression. Predictor variables with $\mathrm{p}$ value less than 0.1 were entered into multiple linear regression model to determine the independent predictors for $\mathrm{MN}$ and $\mathrm{BNC}$ counts. The simple regression analysis (Table III) showed statistically significant associations of $\mathrm{MN}$ and BNC counts with age, duration of marital life, number of pregnancies and positivity for CIN/IC. However the multiple regression analysis revealed that only positivity for CIN/IC $(\beta=0.689$, 
$\mathrm{p}<0.001)$ was significantly associated with $\mathrm{MN}$ count. Age $(\beta=0.135, p=0.383)$, duration of marital life $(\beta=-0.008$, $\mathrm{p}=0.961)$ and number of pregnancies $(\beta=-0.024, \mathrm{p}=0.766)$ were not significantly associated with MN count. Similarly the multiple regression analysis showed that only positivity for CIN/IC $(\beta=0.788, p<0.001)$ was significantly associated with BNC count and age $(\beta=0.121, p=0.357)$, duration of marital life $(\beta=-0.087, p=0.521)$ and number of pregnancies $(\beta=0.057, p=0.410)$ did not show significant associations.

The MN and BNC counts of invasive carcinoma cases were also analyzed with respect to the stage at presentation. Out of the 19 cases of invasive carcinoma, 3 cases presented in stage I (Ia and Ib), 13 in stage II (IIa and IIb) and 3 in stage III (IIIa and IIIb). The MN count and BNC count did not vary significantly with the clinical stage $(\mathrm{p}=0.267$ and 0.487 respectively).

Cells with more than one micronucleus were not observed frequently in our study. They were seen only in cases of HSIL and invasive carcinoma.

We also wanted to examine the utility of $\mathrm{MN}$ and $\mathrm{BNC}$ counts in borderline cases. Hence the MN and BNC counts in 27 ASCUS cases diagnosed initially on cytology were evaluated. ASCUS cases were included only if they had a follow-up biopsy. Six cases had a diagnosis of LSIL and four cases were diagnosed as HSIL on follow-up biopsy. The other cases had an inflammatory outcome on biopsy.
The $\mathrm{MN}$ and $\mathrm{BNC}$ counts in these cases are displayed in Table IV. Mann Whitney-U- test showed a significant difference for $\mathrm{MN}$ and BNC counts in ASCUS cases with inflammatory and CIN outcomes $(\mathrm{p}<0.001$ for both comparisons). The mean \pm SD [median ( min-max)] MN and BNC counts of ASCUS cases with LSIL outcome were $4.7 \pm 1.2[4.5(3.0-6.0)]$ and $5.8 \pm 2.2[5.5(4.0-10.0)]$ and ASCUS cases with HSIL outcome were $13.3 \pm 2.2$ [13.0 $(11.0-16.0)]$ and $19.8 \pm 6.6$ [18.5 (14.0-28.0)].

\section{DISCUSSION}

The present study shows that MN count is significantly greater in HSIL and IC cases compared to LSIL. Our results were similar to other studies (Table V). Olaharski et al. showed that tetraploidy and chromosomal instability occurred early during cervical carcinogenesis and predisposed cervical cells to the formation of aneuploidy. Using a pancentromeric DNA probe, they also demonstrated that micronuclei forming through either chromosomal loss or breakage were significantly elevated in LSIL and HSIL categories. Micronuclei correlated well with tetrasomy and aneusomy (7).

Binucleated cells were not observed frequently in nonneoplastic cases and progressively increased with dysplasia in our study. Binucleated cells are also induced by HPV infection. $\mathrm{Hu}$ et al. have shown that expression of E5 oncoprotein from HPV 16 causes formation of binucleated

Table III: Simple linear regression analysis to identify significant association of various predictors with MN and BNC counts

\begin{tabular}{|l|c|c|c|c|}
\hline & \multicolumn{2}{|c|}{ MN count } & \multicolumn{2}{c|}{ BNC count } \\
\hline Variable & Standardized coefficient $\beta$ & $\mathrm{p}$ value & Standardized coefficient $\beta$ & $\mathrm{p}$ value \\
\hline Age & 0.352 & $<0.001^{\star}$ & 0.349 & $<0.001^{\star}$ \\
\hline Duration of marital life & 0.341 & $<0.001^{\star}$ & 0.336 & $<0.001^{\star}$ \\
\hline Number of pregnancies & 0.236 & $0.008^{\star}$ & 0.284 & $0.001^{\star}$ \\
\hline Number of abortions & 0.088 & 0.331 & 0.094 & 0.295 \\
\hline Positivity for CIN /IC & 0.726 & $<0.001^{\star}$ & 0.814 & $<0.001^{\star}$ \\
\hline
\end{tabular}

* Denotes significant $\mathrm{p}$ values.

MN: Micronucleus, BNC: Binucleated cells, IC: Invasive squamous cell carcinoma

Table IV: MN and BNC counts in ASCUS cases

\begin{tabular}{|l|c|c|c|c|c|}
\hline \multirow{2}{*}{ Category } & \multirow{2}{*}{ Number } & \multicolumn{2}{|c|}{ MN count } & \multicolumn{2}{c|}{ BNC count } \\
\cline { 3 - 6 } & & Mean \pm SD & Median (Min-max) & Mean \pm SD & Median (Min-max) \\
\hline $\begin{array}{l}\text { ASCUS cases with inflammatory } \\
\text { outcome }\end{array}$ & 17 & $2.5 \pm 1.2$ & $3.0(1.0-5.0)$ & $0.7 \pm 0.8$ & $1.0(0.0-2.0)$ \\
\hline ASCUS cases with CIN outcome & 10 & $8.1 \pm 4.7$ & $6.0(3.0-16.0)$ & $11.4 \pm 8.3$ & $8.0(4.0-28.0)$ \\
\hline
\end{tabular}

MN: Micronucleus, BNC: Binucleated cells. 
Table V: Summary of conclusions of studies on MN scoring

\begin{tabular}{|l|l|}
\hline Study & Important Conclusions \\
\hline Guzmán et al. [2003] (12) & Highest MN frequency in HSIL (not significantly higher than LSIL) \\
\hline Reis Campos et al. [2008](13) & CIN correlated with increased MN frequencies \\
\hline Cortés-Gutiérrez et al. [2010] (14) & $\begin{array}{l}\text { Greater MN frequency in women with high-risk HPV types compared with low-risk } \\
\text { types }\end{array}$ \\
\hline Aires et al. [2011] (15) & Higher MN frequency in HSIL compared to LSIL, inflammatory and normal smears \\
\hline Samanta et al. [2011] (16) & $\begin{array}{l}\text { Higher MN scores in HSIL and invasive carcinoma compared to LSIL, inflammation } \\
\text { and normal }\end{array}$ \\
\hline
\end{tabular}

MN: Micronucleus.

cells. Video microscopy and biochemical analyses in their study revealed that HPV 16 E5 produced binucleated cells by inducing cell-cell fusion (17). E5 expression from HPV 6 did not increase binucleated cells. Binucleated cells usually undergo apoptosis due to intrinsic cell cycle checkpoints. However coordinated expression of HPV 16 E6/E7 inhibits p53 and $\mathrm{Rb}$ and facilitates proliferation and transformation of these binucleated cells. Propagation of binucleated cells which have double the amount of chromosomal material can promote genomic instability and induce cervical cancer (17).

The results of the ROC analysis show that $\mathrm{MN}$ and BNC counts possess a high degree of sensitivity and specificity for identifying HSIL+ lesions. Importantly our study also illustrates the utility of $\mathrm{MN}$ and $\mathrm{BNC}$ counts in borderline cases. $\mathrm{MN}$ and BNC counts were significantly higher in ASCUS cases with CIN outcome. Our results show that micronucleus counting is a simple and reliable test that can be done on routine Papanicolaou stained smears and also serves as an effective biomarker for cancer screening.

Several risk factors have been implicated in cervical carcinogenesis. We did not observe any significant variation of $\mathrm{MN}$ and $\mathrm{BNC}$ count with risk factors like age, duration of marital life, number of pregnancies and abortions. The $\mathrm{MN}$ and BNC counts varied significantly only with CIN and invasive carcinoma. Our study does reveal a mild increase of micronuclei formation in infections compared to normal smears. However the increase in MN count in cases with dysplasia is much greater. Reis Campos et al. have also reported increased $\mathrm{MN}$ frequencies with infectious agents like Candida species, Gardnerella vaginalis and HIV (13). Apart from HPV, infections like Trichomonas vaginalis and herpes simplex virus are also related to the subsequent increased risk of cervical neoplasia (18). Infections can induce chronic inflammation and cause genetic damage. It is difficult to understand the effect of risk factors on micronuclei formation because of several confounding variables. Though some of the risk factors can cause a mild increase in $\mathrm{MN}$ counts, a significant increase in $\mathrm{MN}$ frequency seems to be related only to dysplasia.

We did not observe any significant variation of $\mathrm{MN}$ and BNC counts with stage of cervical carcinoma. Gandhi et al. also did not observe a significant variation in the frequency of micronucleated cells with stage of cervical cancer (19).

In conclusion; micronucleus counting is an inexpensive and simple test which can be done satisfactorily on conventional Pap smears and serves as an effective biomarker for cervical cancer screening in conjunction with the routine cytological analysis. It is helpful in borderline cases and can identify CIN cases with cytological diagnosis of ASCUS. Binucleated cell count augments the predictive value of the MN count. A limiting factor in our retrospective study is the small sample size of premalignant lesions. Hence a large scale study is needed.

\section{ACKNOWLEDGMENT}

We are extremely thankful to Dr. Renu G'Boy Varghese, Professor and HOD of Pathology, PIMS for her constant encouragement and critical review of the manuscript.

\section{REFERENCES}

1. Arbyn M, Castellsagué X, de Sanjosé S, Bruni L, Saraiya M, Bray F, Ferlay J: Worldwide burden of cervical cancer in 2008. Ann Oncol 2011, 22:2675-2686

2. Castle PE, Stoler MH, Wright TC Jr, Sharma A, Wright TL, Behrens CM: Performance of carcinogenic human papillomavirus (HPV) testing and HPV16 or HPV18 genotyping for cervical cancer screening of women aged 25 years and older: A subanalysis of the ATHENA study. Lancet Oncol 2011, 12:880-890

3. Bohrer PL, Filho MS, Paiva RL, da Silva IL, Rados PV: Assessment of micronucleus frequency in normal oral mucosa of patients exposed to carcinogens. Acta Cytol 2005, 49:265-272 
4. Zan U, Topaktas M, Istifli ES: In vitro genotoxicity of rocuronium bromide in human peripheral lymphocytes. Cytotechnology 2011, 63: 239-245

5. Almeida TC, Stefanon EB, Rech VC, Sagrillo MR, Bohrer PL: Analysis of oral mucosa of users of crack through micronucleus technique. Clin Lab 2012, 58:1269-1275

6. Samanta S, Dey P: Micronucleus and its applications. Diagn Cytopathol 2012, 40:84-90

7. Olaharski AJ, Sotelo R, Solorza-Luna G, Gonsebatt ME, Guzman P, Mohar A, Eastmond DA: Tetraploidy and chromosomal instability are early events during cervical carcinogenesis. Carcinogenesis 2006, 27:337-343

8. El-Zein RA, Schabath MB, Etzel CJ, Lopez MS, Franklin JD, Spitz MR: Cytokinesis-blocked micronucleus assay as a novel biomarker for lung cancer risk. Cancer Res 2006, 66 : 6449-6456

9. Kaur J, Dey P: Micronucleus to distinguish adenocarcinoma from reactive mesothelial cell in effusion fluid. Diagn Cytopathol 2010, 38:177-179

10. Arora SK, Dey P, Saikia UN: Micronucleus in atypical urothelial cells. Diagn Cytopathol 2010, 38:811-813

11. Wen CH, Lin CH, Tsao SC, Su YC, Tsai MH, Chai CY: Micronucleus scoring in liver fine needle aspiration cytology. Cytopathology 2012 Sep 14. [Epub ahead of print].

12. Guzmán P, Sotelo-Regil RC, Mohar A, Gonsebatt ME: Positive correlation between the frequency of micronucleated cells and dysplasia in Papanicolaou smears. Environ Mol Mutagen 2003, 41:339-343
13. Reis Campos LM, Luz Dias F, Antunes LM, Murta EF: Prevalence of micronuclei in exfoliated uterine cervical cells from patients with risk factors for cervical cancer. Sao Paulo Med J 2008, 126:323-328

14. Cortés-Gutiérrez EI, Dávila-Rodríguez MI, Vargas-Villarreal J, Hernández-Garza F, Cerda-Flores RM: Association between human papilloma virus-type infections with micronuclei frequencies. Prague Med Rep 2010, 111:35-41

15. Aires GM, Meireles JR, Oliveira PC, Oliveira JL, Araújo EL, Pires BC, Cruz ES, Jesus NF, Pereira CA, Cerqueira EM: Micronuclei as biomarkers for evaluating the risk of malignant transformation in the uterine cervix. Genet Mol Res 2011, 10:1558-1564

16. Samanta S, Dey P, Nijhawan R: Micronucleus in cervical intraepithelial lesions and carcinoma. Acta Cytol 2011, 55:42-47

17. Hu L, Plafker K, Vorozhko V, Zuna RE, Hanigan MH, Gorbsky GJ, Plafker SM, Angeletti PC, Ceresa BP: Human papillomavirus 16 E5 induces bi-nucleated cell formation by cell-cell fusion. Virology 2009, 384:125-134

18. Viikki M, Pukkala E, Nieminen P, Hakama M: Gynaecological infections as risk determinants of Subsequent Cervical Neoplasia. Acta Oncol 2000, 39:71-75

19. Gandhi G, Kaur B: Elevated frequency of micronuclei in uterine smears of cervix cancer patients. Caryologia 2003, 56: 217-222 